\title{
PENURUNAN KERAGAMAN GENETIK PADA F-4 IKAN NILA MERAH “CANGKRINGAN" HASIL PEMULIAAN DIDETEKSI DENGAN MARKER GENETIK
}

\author{
Estu Nugroho"), Rustadi*), Dwijo Priyanto ${ }^{* * *}$, Hery Sulistyo $\left.{ }^{* * *}\right)$, Susila ${ }^{* * *}$, \\ Sunaryo ${ }^{* * * *}$, dan Bagus Wasito $\left.{ }^{* * *}\right)$ \\ ) Pusat Penelitian dan Pengembangan Perikanan Budidaya \\ Jl. Ragunan 20, Pasar Minggu, Jakarta Selatan 12540 \\ E-mail:engroho@yahoo.com \\ *) Jurusan Perikanan, Fakultas Pertanian, Universitas Gajah Mada \\ Jl. Flora, Bulaksumur, Yogyakarta 55281 \\ ***) Balai Pengembangan Teknologi Kelautan dan Perikanan, Dinas Kelautan dan \\ Perikanan \\ Jl. Argomulyo, Cangkringan, Sleman, Yogyakarta
}

(Naskah diterima: 20 Februari 2013; Disetujui publikasi: 6 November 2013)

\begin{abstract}
ABSTRAK
Variasi genetik ikan nila merah "Cangkringan" hasil pemuliaan dimonitor dengan menggunakan marker d-Loop DNA untuk mengetahui pembawa keragaman genetik yang dihasilkan karena kegiatan seleksi. DNA diekstraksi dari sirip ikan nila generasi 1 (F-0) hingga generasi ke-5 (F-4) dan diamplifikasi daerah d-Loop pada mitokondria menggunakan primer LH 1509 dan FH 1202. Secara statistik tidak terdapat perbedaan genotipe yang nyata antara ke-5 generasi ikan nila yang diuji. Terdapat penurunan variasi genetik dan kehilangan haplotipe sebesar $25 \%$ dari generasi pertama ke generasi 5 akibat seleksi berdasarkan komposite haplotipe dengan empat enzim restriksi $\mathrm{Mbo}$-l, Hae-III, Rsa-I, dan Alu-I.
\end{abstract}

KATA KUNCl: monitoring variasi genetik, nila merah “Cangkringan”, seleksi

ABSTRACT: Lost of genetic variation of genetically improved strain of "Cangkringan" red tilapia monitored in F-4 detected by DNA Marker. By: Estu Nugroho, Rustadi, Dwijo Priyanto, Hery Sulistyo, Susila, Sunaryo, and Bagus Wasito

Genetic variations of five subsequent generations F-1-F-4 genetically improved red tilapia were monitored by using mtDNA marker to know the change of genetic variation obtained by selection. Genome DNA was extracted from the finclip of red tilapia from generation 1 (F-O) to generation 5 (F-4) and amplified the d-Loop regions of mitokondria using primer LH 1509 and FH 1202. There are statistically not significant genotype differences among five generations analyzed. There are declining genetic variability of $25 \%$ and lost of some composite haplotype from the first to the fifth generations of red tilapia based on the composite haplotype with four restriction enzymes i.e. MboI, Hae-III, Rsa-I, and Alu-I.

KEYWORDS: genetic variation monitoring, red tilapia, selection 


\section{PENDAHULUAN}

Ikan nila adalah salah satu jenis ikan unggulan Kementerian Kelautan dan Perikanan Indonesia baik untuk komoditas ekspor maupun kebutuhan lokal. Ikan ini juga menjadi ikan unggulan dunia untuk pengamanan pangan (food security) karena kemampuan beradaptasi dalam lingkungan yang luas, jenis makanannya bervariasi dan tidak bersaing dengan manusia. Ikan nila adalah pemakan plankton dan bentos sehingga sangat ideal dipelihara dalam kolam yang dipupuk organik ataupun anorganik, juga sangat efisien menggunakan pakan buatan. Ikan nila hidup dalam air tawar dan tahan hidup dalam air asin sehingga potensial untuk dipelihara di tambak. Ikan ini juga tumbuh cepat dan mudah berkembang biak sehingga mudah dalam penyediaan benihnya, tahan hidup dalam air berkualitas rendah, dan tahan terhadap penyakit (Rustadi, 2000).

Ikan nila merah (Oreochromis sp.) merupakan komoditas ekspor pengganti ikan laut red sea bream (Chrysophrys major), disukai oleh konsumen dunia karena memiliki warna daging yang menarik, lezat rasanya dan tidak memiliki duri antar muskular (Behrends et al., 1982). Permintaan nila merah terus meningkat mencapai 30 ton/hari, tetapi belum terpenuhi karena produksinya masih rendah. Oleh karena itu, pengembangan budidaya nila merah diharapkan dapat meningkatkan produksi ikan untuk memenuhi kebutuhan pasar benih untuk ekspor, konsumsi ikan masyarakat, membuka lapangan kerja, dan meningkatkan pendapatan pembudidaya.

Namun demikian pengembangan usaha budidaya ikan nila merah saat ini terdapat permasalahan yaitu adanya indikasi inbreeding yang menyebabkan terjadinya penurunan kualitas genetik (Ariyanto, 2002). Turunnya kualitas genetik dicirikan dengan pertumbuhan lambat, matang kelamin di usia muda, kematian tinggi akibat penurunan daya tahan terhadap penyakit, dan perubahan lingkungan (Sumawijaya et al., 1986). Alternatif untuk mengatasi masalah tersebut adalah dengan upaya pemuliaan, khususnya melalui program seleksi.

Keberhasilan program seleksi selain didukung dari sisi fenotifnya, juga dibutuhkan informasi dari sisi genotipenya untuk melihat keragaman genetik yang dihasilkan akibat kegiatan seleksi. Informasi ini akan memengaruhi langkah berikutnya yang akan diambil dalam menjalankan program seleksi. Penelaahan data dasar genetik ini dapat digunakan untuk mengevaluasi fitness individu jangka pendek dan sintasan suatu populasi untuk jangka panjang (Ferguson et al., 1995).

Salah satu metode yang banyak digunakan untuk analisis keragaman genetik adalah RFLP (Ristriction Fragment Length Polymorphism) pada daerah mitokondria. Menurut Dunham (2004), analisis variasi genetik DNA mitokondria merupakan alternatif untuk mempelajari genetika populasi disebabkan laju mutasi DNA mitokondria lebih cepat dibandingkan dengan DNA genom. Daerah control region salah satunya d-Loop bersifat hipervariabel yang memungkinkan penelusuran evolusi yang lebih cepat. Hasil analisis ini juga seringkali digunakan untuk mengungkapkan keragaman genetik intrapopulasi ikan dalam rangka program perbaikan mutu genetik. Penelitian ini bertujuan untuk mengevaluasi secara genetik keragaman ikan nila merah yang dihasilkan dari kegiatan seleksi dengan menggunakan marker mtDNA d-Loop.

\section{BAHAN DAN METODE}

\section{Ikan Uji}

Ikan uji yang digunakan dalam penelitian ini adalah ikan nila merah "Cangkringan" (yang dirilis dengan nama NILASA pada tahun 2012) mulai dari generasi 1 ( $\mathrm{F}-0$ ) hingga generasi ke-5 (F-4) dalam program seleksi di Balai Pengembangan Teknologi Kelautan dan Perikanan (BPTKP), Yogyakarta. Jumlah total sampel yang digunakan adalah 25 ekor.

Program seleksi yang dilakukan di BPTKP Yogyakarta adalah seleksi individu. Kegiatan diawali dengan pembentukan populasi sintetik dengan mengawinsilangkan empat strain ikan nila merah sebagai bahan populasi yaitu: ikan nila Chitralada, Filipina, NIFI, dan Singapura. Seleksi dilakukan dengan memilih $10 \%$ populasi terbaik pada ikan yang telah mencapai ukuran konsumsi pada setiap generasi. Kegiatan ini diulang hingga mencapai generasi kelima (F-4).

\section{Ekstraksi DNA}

DNA ikan diekstraksi dari potongan sirip dengan menggunakan metode fenol-kloroform sebagai berikut: 5-10 mg potongan sirip ikan dimasukkan ke dalam tabung 1,5 $\mathrm{mL}$ yang telah berisi $500 \mu \mathrm{L}$ larutan TNES Urea. Kemudian 
ditambahkan $10 \mu \mathrm{g} / \mathrm{mL}$ protein kinase dan diinkubasikan pada suhu $37^{\circ} \mathrm{C}$ selama $12 \mathrm{jam}$.

Sebanyak $500 \mu \mathrm{L}$ larutan fenol-kloroform ditambahkan ke dalam tabung di atas untuk selanjutnya dihomogenasi dengan vortex selama satu menit dan disentrifugasi pada kecepatan 10.000 rpm selama sepuluh menit. Lapisan supernatannya diambil dan dimasukkan ke dalam tabung baru, dan ditambahkan $600 \mu \mathrm{L}$ larutan propanol dan di-vortex sampai terlihat endapan putih.

DNA diendapkan menggunakan sentrifugasi campuran tersebut pada kecepatan $10.000 \mathrm{rpm}$ selama sepuluh menit, kemudian larutan bagian atas dibuang dan DNA dikeringkan pada suhu ruangan. Kemudian dilarutkan kembali dalam 50-100 $\mu \mathrm{L}$ buffer TrisEDTA (TE) buffer dan disimpan dalam $4^{\circ} \mathrm{C}$ sebelum digunakan pada tahap selanjutnya.

\section{Amplifikasi Daerah D-Loop}

Amplifikasi d-loop mt-DNA dengan Polymerase Chain Reaction (PCR) menggunakan primer forward LH 1509 (5'-CAT ATT AAA CCC GAA TGA TAT TT-3') dan primer reverse FH 1202 (5'-ATA ATA GGG TAT CTA ATC CTA GTT T-3'). Komposisi bahan untuk amplifikasi DNA adalah $3 \mu \mathrm{L}$ DNA, primer forward $10 \mu \mathrm{M}$, primer reverse $10 \mu \mathrm{M}$, dan $18 \mu \mathrm{L} \mathrm{H}_{2} \mathrm{O}$ yang dicampurkan pada 1 unit taq (ready to go) sehingga volume totalnya menjadi $25 \mu \mathrm{L}$. PCR dilakukan sebanyak 35 siklus.

PCR secara garis besar terdiri atas tiga tahap, yaitu: 1) tahap denaturasi untuk memisahkan DNA menjadi utas tunggal pada suhu $95^{\circ} \mathrm{C}$ selama dua menit; 2) tahap annealling yang merupakan penempelan primer pada DNA utas tunggal pada suhu $50^{\circ} \mathrm{C}$ selama satu menit; 3) tahap ektensi yang merupakan proses pemanjangan DNA baru pada suhu $72^{\circ} \mathrm{C}$ selama dua menit (Baker \& Birt, 2000).

\section{Pemotongan dengan Enzim Restriksi}

Proses pemotongan DNA hasil amplifikasi dengan PCR menggunakan empat jenis enzim restriksi, yaitu: Mbo-I, Hae-III, Rsa-I dan Alu-I. Pemotongan mt-DNA dilakukan dengan mencampurkan $1 \mu \mathrm{L}$ enzim restriksi, $1 \mu \mathrm{L}$ buffer enzim, $3 \mu \mathrm{L}$ DNA hasil PCR, dan $5 \mu \mathrm{L} \mathrm{H}_{2} \mathrm{O}$, kemudian diinkubasi pada suhu $37^{\circ} \mathrm{C}$ selama 24 jam.

Hasil pemotongan kemudian dipisahkan secara elektroforesis dengan menggunakan gel agarose $2 \%$-3\% dalam Tris-Boric-EDTA (TBE) buffer dan diamati dengan illuminator (UV) serta dicetak gambarnya dengan polaroid.

\section{Analisa Data}

Untuk mengevaluasi variasi DNA ikan nila merah dilakukan dengan menggunakan analisa molekuler varians (AMOVA) dan Fst dalam program TFPGA (Miller, 1997). Kekerabatan antar ras dianalisis dengan menggunakan Jarak Genetik, Modified Roger.

\section{HASIL DAN BAHASAN}

Hasil amplifikasi PCR menunjukkan bahwa daerah d-Loop mt-DNA ikan nila merah memiliki panjang sekitar $1.800 \mathrm{bp}$. Hal ini setara dengan ikan nila hitam yang mempunyai ukuran sekitar 1.800-2.000 bp (Nugroho \& Maskur, 2002) dan ikan kancra dengan ukuran panjang d-Loop sekitar 1.800-2.000 bp (Nugroho et al., 2006). Pola hasil pemotongan dengan menggunakan empat enzim tercantum pada Gambar 1 .

Variasi genetik dipengaruhi oleh tingkat generasi ikan. Tercatat pada awal generasi (F-0) ikan nila merah mempunyai nilai haplotipe diversitas sebesar 0,64 dan turun menjadi 0,48 pada generasi kelima (F-4) (Tabel 1 ). Jumlah alel dari empat pada F-0 turun menjadi dua pada F-4. Fenomena ini menjelaskan bahwa kegiatan seleksi merupakan upaya untuk mempersempit atau menurunkan variasi sifat tertentu agar lebih stabil dengan memanfaatkan pengaruh dari inbreeding. Sesuai dengan pendapat Sonesson et al. (2005) yang menjelaskan bahwa inbreeding atau genetic drift akan menurunkan heterozigositas yang terkait dengan variasi genetik.

Selanjutnya tercatat bahwa nilai keragaman pada awalnya naik terlebih dahulu yaitu menjadi 0,72 pada $\mathrm{F}-2$ dan $\mathrm{F}-3$ sebelum turun pada F-4, menunjukkan kemungkinan masih adanya efek heterosis pada populasi yang diamati mengingat populasi sintetik terbuat dari persilangan antara 4 strain. Sonesson et al. (2005) berpendapat bahwa jika satu atau beberapa individu yang tidak mempunyai kekerabatan digunakan sebagai induk dalam program seleksi maka inbreeding pada benihnya bisa berkurang sampai nol. Hal ini berarti pula efek heterosisnya masih dapat muncul. Sebaliknya pada F-4, nilai keragaman genetiknya sudah turun hingga $25 \%$ dari awal generasi memperlihatkan bahwa program seleksi dengan memanfaatkan inbreeding mulai berdampak pada generasi kelima (F-4). 

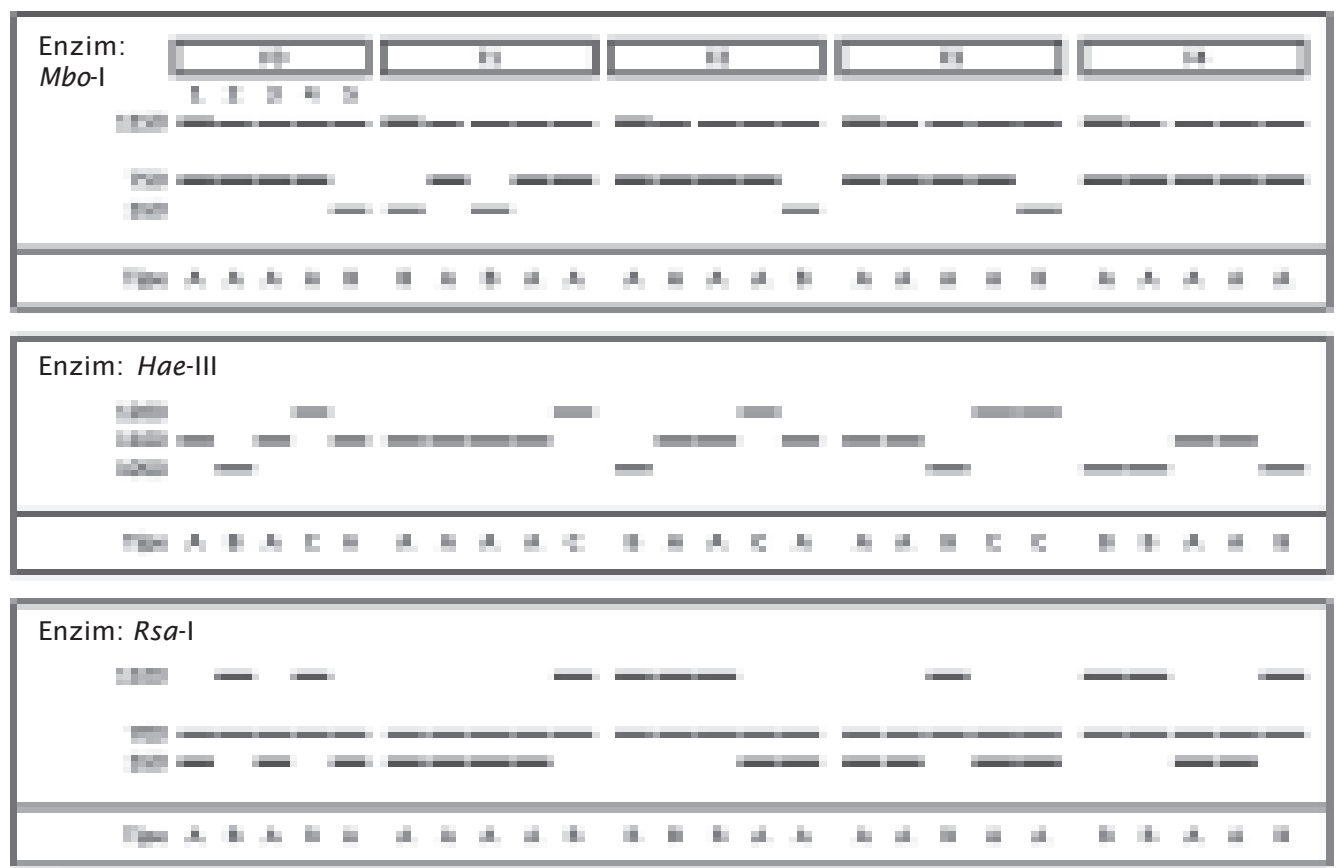

Enzim: Alu-I

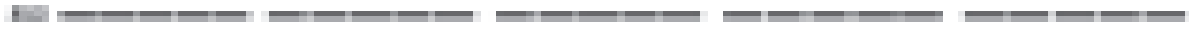

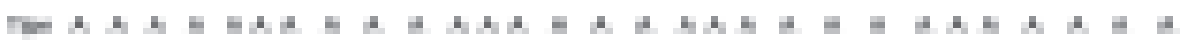

Gambar 1. Pola pemotongan hasil amplifikasi daerah d-Loop dengan menggunakan empat enzim restriksi

Figure 1. Restriction patterns of amplificated d-Loop regions using four restriction enzymes

Tabel 1. Variasi genetik ikan nila merah dari lima generasi

Table 1. Genetic variation of five generations of red tilapia

\begin{tabular}{lccccc}
\hline \multirow{2}{*}{$\begin{array}{c}\text { Haplotipe } \\
\text { Haplot ype }\end{array}$} & \multicolumn{5}{c}{ Populasi (Population) } \\
\cline { 2 - 6 } & F-0 & F-1 & F-2 & F-3 & F-4 \\
\hline AAAA & 0.400 & 0.400 & - & 0.400 & 0.400 \\
ABBA & 0.200 & - & 0.200 & 0.200 & 0.600 \\
ACBA & 0.200 & 0.200 & - & - & - \\
BAAA & 0.200 & 0.400 & 0.200 & & \\
AABA & - & - & 0.400 & - & - \\
ACAA & - & - & 0.200 & 0.200 & - \\
BCAA & - & - & - & 0.200 & - \\
N-sampel (Sample- $N$ ) & 5 & 5 & 5 & 5 & 5 \\
N-allele & 4 & 3 & 4 & 4 & 2 \\
Ke ragaman haplotipe & 0.640 & 0.640 & 0.720 & 0.720 & 0.480 \\
Haplotype diversity & & & & & \\
\hline
\end{tabular}


Secara statistik tidak terdapat perbedaan genetik (genotipe) yang nyata antar kelima generasi ikan nila merah yang diuji (Tabel 2 ). Hal ini dimungkinkan semua strain yang digunakan sebagai populasi sintetik telah berbaur dengan baik sehingga sama-sama berkontribusi alel pada generasi berikutnya. Jika tidak sama-sama berkontribusi maka akan timbul satu atau lebih alel yang bersifat spesifik dengan persentase yang besar sehingga menimbulkan perbedaan yang nyata. Selang kepercayaan pada uji FST berpasangan ini berkisar antara 0,1298 (F-1 x F-4) hingga 1,0 (F-0 x F-3 dan F-0 x F-4). Nilai ini juga menandakan bahwa turunan pada F-3 dan F-4 lebih berkaitan dengan $\mathrm{F}-0$, dibandingkan antara F-1 dan F-2 dengan F-0.

Jarak genetik modifikasi Roger rata-rata adalah 0,414 (Tabel 3). Nilai terendah jarak genetik terdapat pada pasangan generasi $\mathrm{F}-0-\mathrm{F}-4$ yaitu 0,200 dan yang terbesar dengan nilai 0,529 terdapat pada pasangan generasi F-1-F-4 dan F-2-F-4. Keadaan ini memperkuat

Tabel 2. Hasil uji Fst berpasangan

Table 2. Result of pairwise Fst test

\begin{tabular}{cccccc}
\hline & \multicolumn{5}{c}{ Populasi (Population) } \\
\cline { 2 - 7 } & F-0 & F-1 & F-2 & F-3 & F-4 \\
\hline F-0 & - & - & - & - & - \\
F-1 & 0.419 & - & - & - & - \\
F-2 & 0.305 & 0.299 & - & - & - \\
F-3 & 1.000 & 0.452 & 0.623 & - & - \\
F-4 & 1.000 & 0.129 & 0.140 & 0.716 & - \\
\hline
\end{tabular}

Keterangan (Note):

$\mathrm{P}<0,05$ berbeda nyata (Significant different)

Tabel 3. Jarak genetik modifikasi Roger

Table 3. Modified Roger genetic distance

\begin{tabular}{cccccc}
\hline & \multicolumn{5}{c}{ Populasi (Population) } \\
\cline { 2 - 6 } & F-0 & F-1 & F-2 & F-3 & F-4 \\
\hline F-0 & - & - & - & - & - \\
F-1 & 0.400 & - & - & & - \\
F-2 & 0.489 & 0.489 & - & - & - \\
F-3 & 0.283 & 0.400 & 0.477 & - & - \\
F-4 & 0.200 & 0.529 & 0.529 & 0.346 & - \\
\hline
\end{tabular}

hasil uji Fst berpasangan bahwa individuindividu pada generasi F-4 lebih serupa dengan individu-induvidu pada generasi awal $\mathrm{F}-0$. Lebih jelas terlihat pada dendrogram jarak genetik (Gambar 2) yaitu F-0 dan F-4 berdekatan, sedangkan F-2 terletak paling jauh dengan posisi F-0 (populasi sintetik).

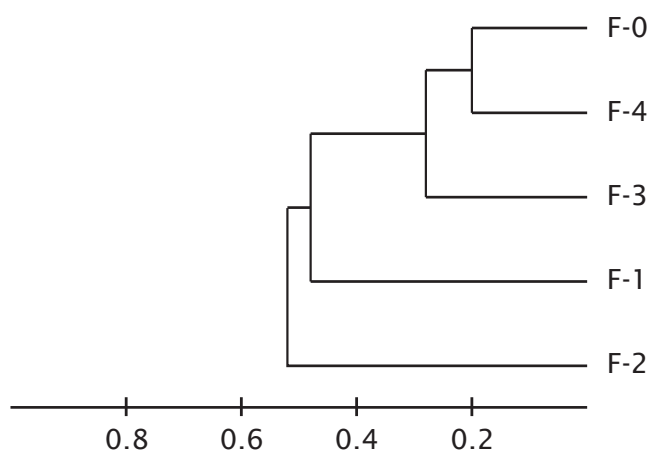

Gambar 2. Dendogram ikan nila merah "Cangkringan" berdasarkan frekuensi haplotipe mt-DNA d-Loop dengan empat enzim restriksi

Figure 2. Dendogram of "Cangkringan" red tilapia based on the haplotype frequency of d-Loop mt-DNA with four restriction enzymes

\section{KESIMPULAN}

Secara statistik tidak terdapat perbedaan genotipe yang nyata antar ikan nila merah dari generasi 1 (F-0) sampai generasi 5 (F-4). Terdapat penurunan keragaman hingga $25 \%$ dari F-0 ke F-4 sebagai akibat dari seleksi.

\section{DAFTAR ACUAN}

Ariyanto, D. 2002. Analisis keragaman bentuk tubuh ikan nila strain GIFT pada tiga tingkatan umur yang berbeda. Universitas Gadjah Mada, Yogyakarta. Jurnal Perikanan, IV(1): 19-26.

Behrends, L.L., Nelson, R.G., Smitherman, R.O., \& Stone, N.M. 1982. Breeding and culture of the red-gold color phase of tilapia. J. World Maricul. Soc., 13: 210-220.

Baker, A.J. \& Birt, P. 2000. Polymerase Chain Reaction molecular methods in ecology. Blackwell Science Ltd. Oxford.

Dunham, R.A. 2004. Aquaculture and fisheries biotechnology. Genetic Approaches. U.K. Cabi Publishing. 
Ferguson, A., Taggart, J.B., Prodohl, P.A., Mc.Meel, O., Thompson, C., Stone, C., McGinnity, P., \& Hynes, R.A. 1995. The application of molecular markers to the study and conservation of fish population, with special reference to Salmo. Journal of Fish Biology, 47: 103-126.

Miller, M.P. 1997. Tools for Population Genetic Analysis (TFPGA). Version 1.3. Department of Biological Science, Northern Arizona University, Flagstaff.

Nugroho, E., Subagja, J., Asih, S., \& Kurniasih, T. 2006. Evaluasi keragaman genetik ikan kancra dengan menggunakan marker mtDNA d-Loop dan Random Amplified Polymorphism DNA (RAPD). 2006. J. Ris. Akuakultur, 1(2): 211-217.
Nugroho, E. \& Maskur. 2002. Benarkah ikan nila merah adalah hasil hibrid? Warta Penelitian Perikanan Indonesia, 8(1): 7-11.

Rustadi. 2000. Pengembangan rancang bangun keramba jaring apung yang ramah lingkungan untuk budidaya nila merah (Oreochromis sp.) di perairan waduk. Laporan Penelitian DIK-S UGM. Yogyakarta, $20 \mathrm{hlm}$.

Sumawijaya, K., Bari, A., \& Wiratmadja, G. 1986. Teknik seleksi ikan. Prosiding Loka Karya Nasional Teknologi Tepat Guna Bagi Pengembangan Perikanan Budidaya Air Tawar. Balitkanwar, hlm. 27-33.

Sonesson, A.K., Woolliams, J.A., \& Meuwissen, T.H.E. 2005. Kinship, Relationship and Inbreeding. In Selection and breeding programs in aquaculture. (Ed.) Gjedrem, T. Springer. AKVAFORKS, p. 73-84. 